蛋白質／蛋白質相互作用による物質輸送機能発現の機構 アミノ酸トランスポーターの構成サブユニットと機能・調節の多樣性 金井 好克

(杏林大学医学部・薬理学教室)

1.

細胞膜を介する物質輸送は、トランスポーター (輸送体) と呼ばれる膜タンパク質によって行われ る。従来トランスポーターは、単一のタンパク質て機能すると考えられていたが、我々は哺乳類アミノ 酸トランスポーターの分子クローニングの過程で、へテロ 2 量体構造をとるトランスポーターを見出し た。本研究は、アミノ酸トランスポーターの構成サブユニットを明らかにし、タンパ質間相互作用によ り機能と調節の多樣性が生みだされる機構を明らかにすることを目指した。

\title{
2. 研究結果及び自己評価
}

研究結果

(1) アミノ酸トランスポーターの構成サブユニットの同定

我々がすで明らかにしていたへテロ 2 量体型アミノ酸トランスポーターは 12 回膜貫通型の主サ ブユーット LAT1 (L- type amino acid transporter 1) と1回膜貫通型の補助サブユニット 4F2he (4F2 抗 原重鎖;CD98) が、ジスルフィド結合により連結することによって形成される。本研究において、LAT1 と類似のタンパク質をコードする cDNA を単離することにより、6種の新規主サブユニットを同定し、

LAT1 及び他のグループによる2種をあわせて、多樣な基質選択性を示す 9 種の主サブユニットから なるへテロ2量体型トランスポーターファミリーを確立した。このファミリーのメンバーのうち、LAT1を はじめとする6種は、補助サブユニット 4F2hcと連結し、1種は4F2hc 類似の構造を持つ rBAT (related

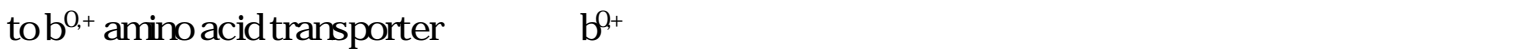
結合を介して連結する。残りの 2 種は、未知の補助因子と連結すると考えられる。

( 2 ) 補助サブユニットの役割

ヘテロ2量体型トランスポーターファミリーは、特定の補助サブユニットと連結し、タンパク質複合体 として、細胞膜へと輸送される。極性細胞においては、現在同定されている2種の補助サブユニット 4F2hc 及びr rBAT は、弚れ光れ側底側細胞膜、頂端䚋細胞膜への移行シグナルを内在すると考えら れる。2種の補助サブユニットの分子キメラを作製することにより、主サブユニットの認識に関わる領 域、及び細胞膜移行を決定する領域の解析が推行中である。

補助サブユニット 4F2hc は、インテグリン beta-1サブューットと連結し、主サブユニットを加えて高 分子複合体を形成することが免疫沈降により明らかになった。さらに、yeast two hybrid 法により、 4F hhc の細胞内ドメインと相互作用するタンパク質力同定され、4F2hc カ細胞内外のシグナル経路と 連結し、主サブユニットの機能を調節する可能性が示唆された。

( 3 ） 細胞增殖におけるアミノ酸トランスポーターの役割

LAT1 は、悪性腫場細胞に発現力沉進する。ヒ卜悪性腫場細胞株 T24 は、インヒビターやアンチセ ンス DNA による LAT1の抑制により細胞增殖力抑制された。この増殖抑制は、細胞死の誘発ではな く、細胞周期全体の延長によることか沶唆された。また、LAT1 の強制発現により、細胞増殖か促進 することか明らかとなった。従って、LAT1 を介するアミノ酸の取り込みが、細胞增殖の律速段階の一 つとなると考えられる。

LAT1/4F2hc 複合体の役割を in vivo て検討する目的で、CDNA をインスリンプロモーターに繋い て膵蔵 $\mathrm{b}$ 細胞に過来溌現させるトランスジェニックマウスを作製した。トランスジェニック個体の愺臓で は、ランゲルハンス島カ肥大し、beta 細胞の配列の乱れと増殖像か観察され、LAT1／4F2hc 複合 体の細胞增殖促進効果が支持された。

( 4 ) 今後の展望

1 回膜貫通型の補助サブユニットを中心に複数のタンパク質が連結し、トランスポーターの機能が 細胞内外の情報伝達系の web の中て調節され、細胞及び組織の恒常性カ濰持される機構を、本研 究の延長上に明らかにしたい。また、本研究でアミノ酸トランスポーターカ細胞增殖の律速段階のひ とつとなることが示されたが、乥の抑制による細胞周期延長の機序の解明と、悪性腫瘍治療への応 用の可能性の探究が今後の課題となる。 
自己評価

本研究は、従来単一の分子で機能するとされていたトランスポーターが複数の分子の複合体として 形成される事例を提示した。本研究により、トランスポーター研究に「タンパク質間相互作用」の概念 が導入され、この研究分野のポストゲノム研究への橋渡しがなされた。トランスポーター分子複合体 の、他の細胞構成タンパク質との機能的連結等の問題は残されたが、研究開始時の到達目標の骨 子は実現されたと考える。

\section{3 . 領域総括の見解}

哺乳類のアミノ酸トランスポーターは、12 回膜貫通型の主サブユニットと 1 回膜貫通型の補助サブ ユニットからなることが、本研究者のこれまで研究て明らかとなっていた。本研究期間では、二種類 の異なる補助サブユニットについて対比しながら機能を調べ、これらが主サブユニットの活性調節、 ひいては細胞増殖制御に働くことを見出した。炎の全容か明らかになれば、悪性腫瘍の治療に応用 される可能性が示唆される。

4 . 主な論文

1. Segawa, H., Fukasawa, Y., Miyamoto, K., Takeda, E., Endou, H., and Kanai, Y. (1999). Identification and functional characterization of a $\mathrm{Na}^{+}$- independent neutral amino acid transporter with broad substrate selectivity. J . Biol. Chem. 274. 19745- 19751.

2. Chairoungdua, A., Segawa, H., Kim, J.Y., Miyamoto, K., Haga, H., Fukui, Y., Mizoguchi, K., Ito, H., Takeda, E ., Endou, H ., and Kanai, $Y$. (1999). Identification of an amino acid transporter associated with the cystinuria- related type II membrane glycoprotein. J. Biol. Chem. 274. 28845- 28848.

3. Fukasawa, Y., Segawa, H., Kim, J.Y., Chairoungdua, A., Kim, D.K., Matsuo, H., Cha, S.H., Endou, H., and Kanai, $\mathrm{Y}$. (2000). Identification and characterization of a $\mathrm{Na}^{+}$- independent neutral amino acid transporter that associates with the $4 \mathrm{~F} 2$ heavy chain and exhibits substrate selectivity for small neutral D- and L- amino acids. J. Biol. Chem. 275. 9690-9698.

4 Kanai, Y., Fukasawa, Y., Cha, S.H., Segawa, H., Chairoungdua, A., Kim, D.K., Matsuo, H ., Kim, J.Y., Miyamoto, K., Takeda, E., and Endou, H. (2000). Transport properties of a system $y^{+} \mathrm{L}$ neutral and basic amino acid transporter: Insights into the mechanisms of substrate recognition. J. Biol. Chem. 275. 20787-20793.

5. Kim, D.K., Kanai, Y., Chairoungdua, A., Matsuo, H., Cha, S.H., and Endou, H. (2001).Expression cloning of a $\mathrm{Na}^{+}$-independent aromatic amino acid transporter with structural similarity to $\mathrm{H}^{+}$/monocarboxylate transporters. J. Biol. Chem. 276. 17221- 17228.

5. 光の他

招待講演 : 国内 21 件、海外 5 件

特許出願：「広い基質選択性を有する中性アミノ酸トランスポーター及び炎の遺伝子」 (特開 2000-342270) 